\title{
PEMANFAATAN TEKNOLOGI INFORMASI DAN KOMUNIKASI \\ DALAM PENERAPAN KONSEP SMART TOURISM DI KABUPATEN PANGANDARAN
}

\author{
Rifki Rahmanda Putra \\ Universitas Padjadjaran, Bandung \\ Email: Rifki18005@mail.unpad.ac.id \\ Ute Lies Siti Khadijah \\ Universitas Padjadjaran, Bandung \\ Email: ute.lies@unpad.ac.id \\ Cecep Ucu Rakhman \\ Sekolah Tinggi Pariwisata Bandung \\ Email: cecep.u.r@gmail.com
}

\begin{abstract}
Information and communication technology have changed globally specifically in the industrial era 4.0. Pangandaran Regency which focuses its economy through the tourism industry and aspires its region as a world-class tourist destination needs to accelerate its tourism development through the development of information and communication technology with the concept of smart tourism, to initiate an increase with the need to visit tourists. So this study discusses the use of potential and develops the concept of intelligent tourism in The Pangandaran Regency by utilizing information and communication technology to accelerate to become a world-class tourist destination. The method used in this research is qualitative research with case studies, with interactive model analysis techniques. The results showed that the potential of smart tourism in The Pangandaran Regency is a technology-based infrastructure that supports websites, social media, recommendation systems and also the number of millennial tourists. While the development of the concept of smart tourism is divided into the factors of demand and supply with collaboration while the manager of the destination, and the development of intelligent technology by considering Big Data and supporting factors for efficient digital marketing.
\end{abstract}

Keywords : smart tourism, Pangandaran Regency, information and communication technology 


\section{Pendahuluan}

Teknologi Informasi Komunikasi (TIK) telah mengubah pariwisata secara global khususnya pada era 4.0. Rekayasa ulang yang didorong oleh TIK telah secara bertahap menghasilkan pergeseran paradigma baru, mengubah struktur industri dan mengembangkan berbagai peluang dan ancaman. TIK memberdayakan konsumen untuk mengidentifikasi, menyesuaikan dan membeli produk-produk pariwisata dan mendukung globalisasi industri dengan menyediakan alat untuk mengembangkan, mengelola, dan mendistribusikan penawaran di seluruh dunia. Semakin, TIK memainkan peran penting untuk daya saing organisasi dan tujuan pariwisata (Buhalis 1998, 2003; Poon 1993; Sheldon 1997; O'Connor 1999). TIK menjadi penentu utama daya saing organisasi dan berbagai perkembangan teknologi mendorong evolusi ini.

Dalam industri pariwisata, pergeseran tren yang semula secara konvensional orang berbondong ke biro perjalanan apabila hendak mengatur perjalanannya, kini mayoritas wisatawan telah dipermudah dengan hanya melalui sentuhan jari pada layar smartphone untuk menentukan destinasi, akomodasi, hingga pelayanan pariwisata lainnya. Hal tersebut tentu didukung dengan perkembangan TIK yang semakin pesar di Era 4.0 ini.

Internet, data, dan artificial intelligence adalah sederet teknologi yang menopang revolusi industri 4.0 ini (Heliany, I, 2019). Indonesia sendiri merupakan negara ke- 6 pengguna internet terbanyak (lihat tabel 1). Di mana di dalam industri pariwisata sendiri, penggunanya didominasi oleh wisatawan milenial. Di tingkat Asia sendiri, wisatawan milenial berjumlah seperempat dari populasi di wilayah Asia secara keseluruhan (Noviyanti, 2014) dan 20\% dari keseluruhan wisatawan mancanegara (Mohn, 2014). 
Pemanfaatan Teknologi Informasi dan Komunikasi dalam Penerapan Konsep Smart Tourism...

Tabel 1. Jumlah Pengguna Internet Berdasarkan Negara Asal

\begin{tabular}{lll}
\hline No & Negara Asal & $\begin{array}{l}\text { Pengguna Internet Tahun } 2018 \\
\text { (dalam juta jiwa) }\end{array}$ \\
\hline 1 & China & 777 \\
2 & US & 274,1 \\
3 & India & 346,3 \\
4 & Brazil & 125,9 \\
5 & Japan & 105,4 \\
6 & Indonesia & 123,0 \\
\hline
\end{tabular}

Sumber: Kominfo.go.id (2018)

Seiring dengan pesatnya era digital di seluruh belahan dunia, maka kemajuan ekonomi di Indonesia mendapat dukungan dari suksesi sektor TIK (Dewantara, 2015). Melihat potensi tersebut, sudah seharusnya industri pariwisata di Indonesia memanfaatkan TIK dengan strategi digital marketing untuk promosi pariwisata nya. TIK yang sukses membutuhkan manajemen inovatif untuk terusmenerus meninjau perkembangan dan mengadopsi solusi teknologi yang sesuai untuk memaksimalkan daya saing destinasi (Buhalis, 2005).

Kabupaten Pangandaran merupakan salah satu Daerah Otonomi Baru (DOB) di Provinsi Jawa Barat Indonesia yang membutuhkan pemanfaatan TIK dalam percepatan pembangunan keparwisataannya. Karena DOB ini menitikberatkan sektor perekonomiannya melalui industri pariwisata dengan visi besarnya yaitu "Menjadi Destinasi Wisata Kelas Dunia". Menurut RIPPARNAS 2010-2025 kabupaten ini juga termasuk ke dalam Kawasan Strategis Pariwisata Nasional (KSPN) dengan penekanan tema pengembangan wisata mengedepankan pada aktivitas wisata bahari dan minat khusus. 
Namun demikian, pertumbuhan sektor pariwisata yang seharusnya terakselerasi dengan penetapan KSPN dan DOB berbanding terbalik dengan performa Pangandaran yang ditunjukkan dengan kunjungan wisatawan mancanegara yang semakin menurun dalam 4 tahun terakhir ini (lihat tabel 2). Hal tersebut diduga karena pengembangan promosi pariwisata yang kurang optimal.

Tabel 2. Jumlah Kunjungan Wisatawan Mancanegara ke Pangandaran

\begin{tabular}{ll}
\hline Tahun & Jumlah Wisatawan Mancanegara \\
\hline 2016 & 11022 \\
2017 & 11449 \\
2018 & 8194 \\
2019 & 5276 \\
\hline
\end{tabular}

Sumber: Disparbud Kab. Pangandaran (2019)

Salah satu dugaan dari menurunnya angka kunjungan wisatawan mancanegara tersebut karena kurangnya promosi pariwisata itu sendiri, dibenarkan oleh Sekretaris Dinas Pariwisata dan Kebudayaan Kabupaten Pangandaran, yang menyatakan bahwa:

“....sejauh ini wisatawan mancanegara menurun terus... kami belum melakukan kegiatan pemasaran yang lengkap. Kami baru dalam tahap menata destinasi pariwisata" (Kusumawati, Lilis., 18/10/2019)

Dalam kutipan wawancara pra survey tersebut, terlihat bahwa arah pembangunan kepariwisataan Pangandaran, dirancang untuk menata destinasi nya terlebih dahulu, sebelum memasarkannya. Hal ini sangat ironis sebab sebenarnya dengan memanfaatkan TIK dengan konsep e-tourism (pariwisata berbasis elektronik) dapat memberikan setidaknya dua manfaat, yaitu murah dan cepat (memotong jalur distribusi) dalam hal promosi pariwisata (Dewantara, 2015). Bauran pemasaran pariwisata terhadap destinasi wisata harus dipertimbangkan sebagai tolak ukur 
Pemanfaatan Teknologi Informasi dan Komunikasi dalam Penerapan Konsep Smart Tourism...

dalam meningkatkan pemasaran pariwisata ke arah yang lebih baik dan dapat meningkatkan jumlah kunjungan wisatawan secara signifikan di tiap tahunnya (Puspawigati, 2014).

Artinya, promosi pariwisata merupakan aspek penting dari pembangunan kepariwisataan untuk mengakselerasi Pangandaran sebagai destinasi wisata kelas dunia dan prosesnya harus tetap berjalan beriringan dengan pengembangan destinasi. Dalam hal ini TIK dapat memudahkan konsumen untuk mengidentifikasi, menyesuaikan dan membeli produk-produk pariwisata misalnya melalui pengembangan teknologi dan promosi yang mendunia (Buhalis, 2005).

Konsep pariwisata yang memanfaatkan TIK dapat juga didefinisikan sebagai e-tourism atau smart tourism (Benckendorf et al, 2014). Sebuah destinasi dapat dikatakan smart apabila destinasi tersebut memanfaatkan infrastruktur teknologi secara intensif untuk: (1) meningkatkan pengalaman berwisata bagi pengunjung pengunjung dengan mempersonalisasikan dan membuat mereka sadar akan layanan dan produk lokal dan pariwisata yang tersedia untuk mereka di tempat tujuan dan (2) dengan memberdayakan organisasi manajemen destinasi, lembaga lokal dan perusahaan pariwisata untuk membuat keputusan dan mengambil tindakan berdasarkan data yang dihasilkan di dalam tujuan, dikumpulkan, dikelola dan diproses melalui infrastruktur teknologi (Lamsfus et al., 2015).

Maka dari itu penelitian ini bertujuan untuk: (1) mengidentifikasi potensi penerapan konsep smart tourism di Kabupaten Pangandaran; dan (2) mengembangkan konsep smart tourism di Kabupaten Pangandaran dengan memanfaatkan TIK untuk akselerasi menjadi destinasi wisata kelas dunia. Karena, dengan menerapkan konsep smart tourism akan menjamin pengembangan kawasan wisata yang berkelanjutan, dapat diakses oleh semua orang, dapat memfasilitasi interaksi pengunjung dan meningkatkan kualitas pengalaman di destinasi, dan meningkatkan kualitas hidup penduduk setempat (Lopez de Avila, 2015). 


\section{Teori}

\section{Definisi Smart Tourism}

Smart Tourism adalah pemanfaatan segala potensi dan sumber daya yang ada untuk meningkatkan pengalaman di bidang Pariwisata. Konsep smart tourism lahir dari pengembangan kajian mengenai hubungan teknologi dan bidang pariwisata (Gajdosik, 2018). Smart Tourism adalah perkembangan logis dari pariwisata tradisional yang berkembang menjadi e-tourism karena dasar inovasi dan orientasi teknologi industri dan konsumen diletakan diawal dengan adopsi ICT yang luas dalam kegiatan pariwisata (Werthner \& Ricci, 2004).

\section{Model Smart Tourism}

Konsep smart dalam smart tourism merupaka hasil dari pengembangan inovasi teknologi dan informasi (Gajdosik, 2018). Adapun model yang digunakan dalam penelitian ini adalah model penciptaan smart tourism experience melalui pemanfaatan: (1) Big Data kepariwisataan; (2) dikelola oleh DMO pariwisata dan perusahaan teknologi; (3) ada permintaan dari wisatawan smart; (4) didukung dengan infrastruktur berbasis teknologi dan smart technology; dan (5) memperhatikan digital marketing yang efisien (Femenia-Serra \& Neuhofer, 2019).

\section{Metode}

Metode yang digunakan dalam penelitian ini adalah metode penelitian kualitatif dengan pendekatan studi kasus. Penelitian kualitatif dilakukan melalui kontak intens dengan informan dengan setting yang asli untuk menelusuri atau menyelidiki fenomena yang terjadi baik dalam kehidupan individu, kelompok, masyarakat dan organisasi (Miles, Huberman \& Saldana, 2014).

Penelitian ini berfokus pada Destinasi Pariwisata Kabupaten Pangandaran dengan isu pengembangan promosi pariwisata melalui pemanfaatan TIK dan konsep smart tourism. Informan penelitian dipilih dengan teknik purposive snowball 
Pemanfaatan Teknologi Informasi dan Komunikasi dalam Penerapan Konsep Smart Tourism...

sampling yaitu dengan menentukan informan kunci (SKPD Kepariwisataan Kabupaten Pangandaran dan Pengelola Daya Tarik Wisata) terlebih dahulu, kemudian pada akhir wawancara peneliti menanyakan kepada tiap informan, siapa saja stakeholder yang dapat menjawab pertanyaan wawancara dengan komprehensif.

Pengumpulan data pada penelitian ini menggunakan teknik wawancara tidak terstruktur atau indepth interview dan observasi lapangan untuk pengumpulan data primer dan studi literatur untuk pengumpulan data sekunder, baik itu dari dokumen kebijakan terkait, arsip pengelola, buku atau karya tulis ilmiah lainnya dan data internet. Sedangkan teknik analisis pada penelitian ini adalah model interaktif yaitu kegiatan: 1) kondensasi data, 2) penyajian data, dan 3) penarikan kesimpulan atau verifikasi data (Miles, Huberman \& Saldana, 2014).

\section{Pembahasan}

Model yang digunakan dalam penelitian ini untuk mengidentifikasi potensi Pangandaran sebagai smart tourism destination dan upaya pengembangan konsep smart tourism di Pangandaran dalam penelitian ini, mengacu kepada model smart tourism experience yang dikembangkan Femenia-Sera \& Neuhofer (2019). Maka dari itu hasil dan pembahasan penelitian ini adalah sebagai berikut:

\section{Potensi Pangandaran sebagai Smart Tourism Destination}

\section{Infrastruktur Berbasis Teknologi}

Dalam aspek infratruktur berbasis teknologi, dapat diklasifikasikan menjadi sinyal pandu, sensor, kartu pintar, sosial media, website, VR, AR, Apps, Wi-fi umum, Qr Codes, recommendation systems. Di Pangandaran sendiri, media promosinya dapat dibilang sudah Go Digitial meskipun belum sepenuhnya optimal. Karena sudah ada unsur sosial media, website, dan recommendation systems (lihat gambar 1, 2, \& 3). Namun demikian ada beberapa unsur yang belum terbangun apabila hendak menerapkan konsep smart tourism. 


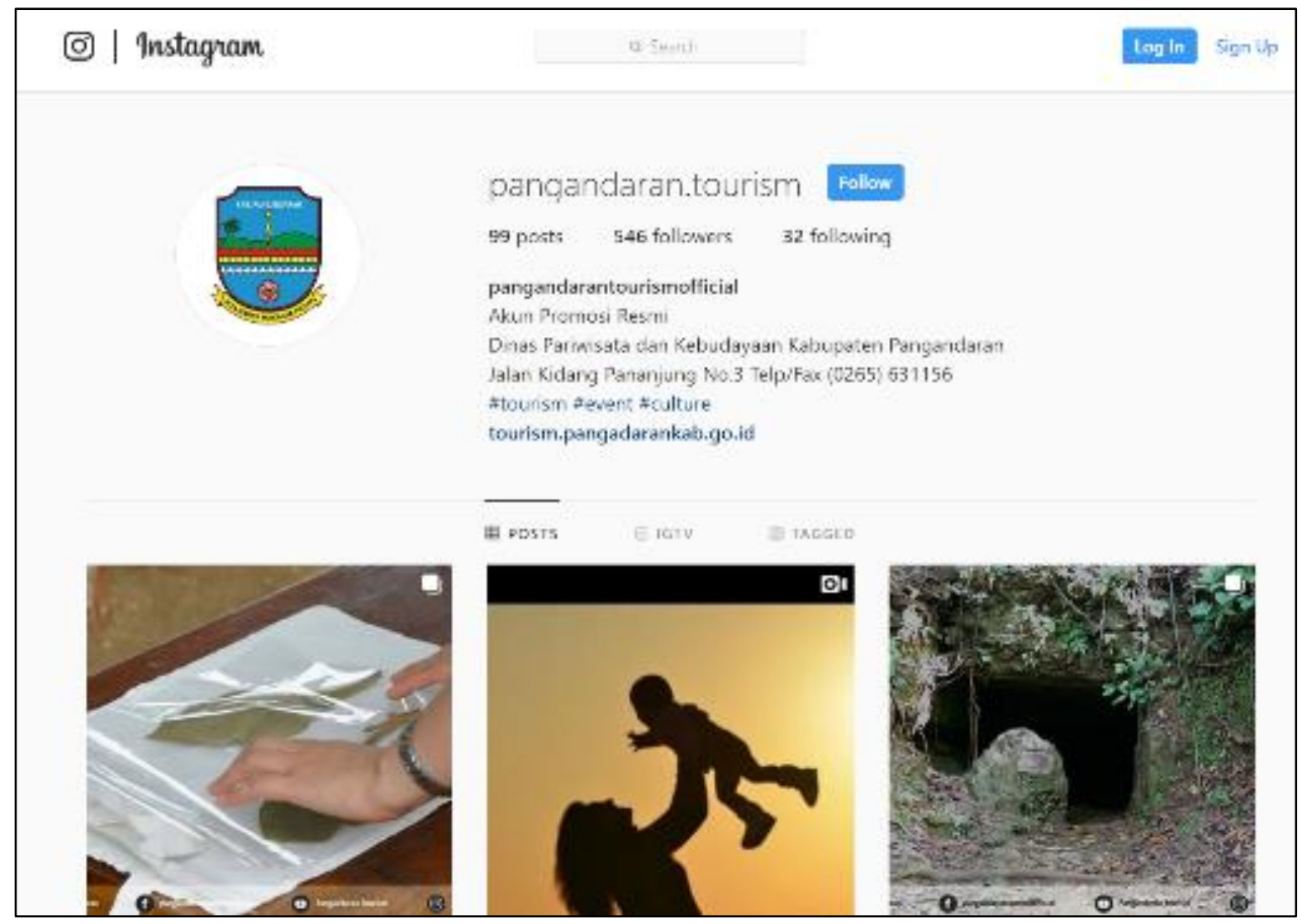

Gambar 1 Sosial Media Instagram Pariwisata Pangandaran Sumber: IG Pangandaran Tourism (2020)

Sudah terdapat fitur sosial media pariwisata Pangandaran di Instagram dengan nama "pangandaran.tourism" yang dikelola oleh Dinas Pariwisata dan Kebudayaan Kabupaten Pangandaran. Di dalamnya terdapat beragam katalog pariwisata Pangandaran mulai dari potret daya tarik wisata, kuliner, kerajinan dan beragam info event untuk media informasi wisatawan. 


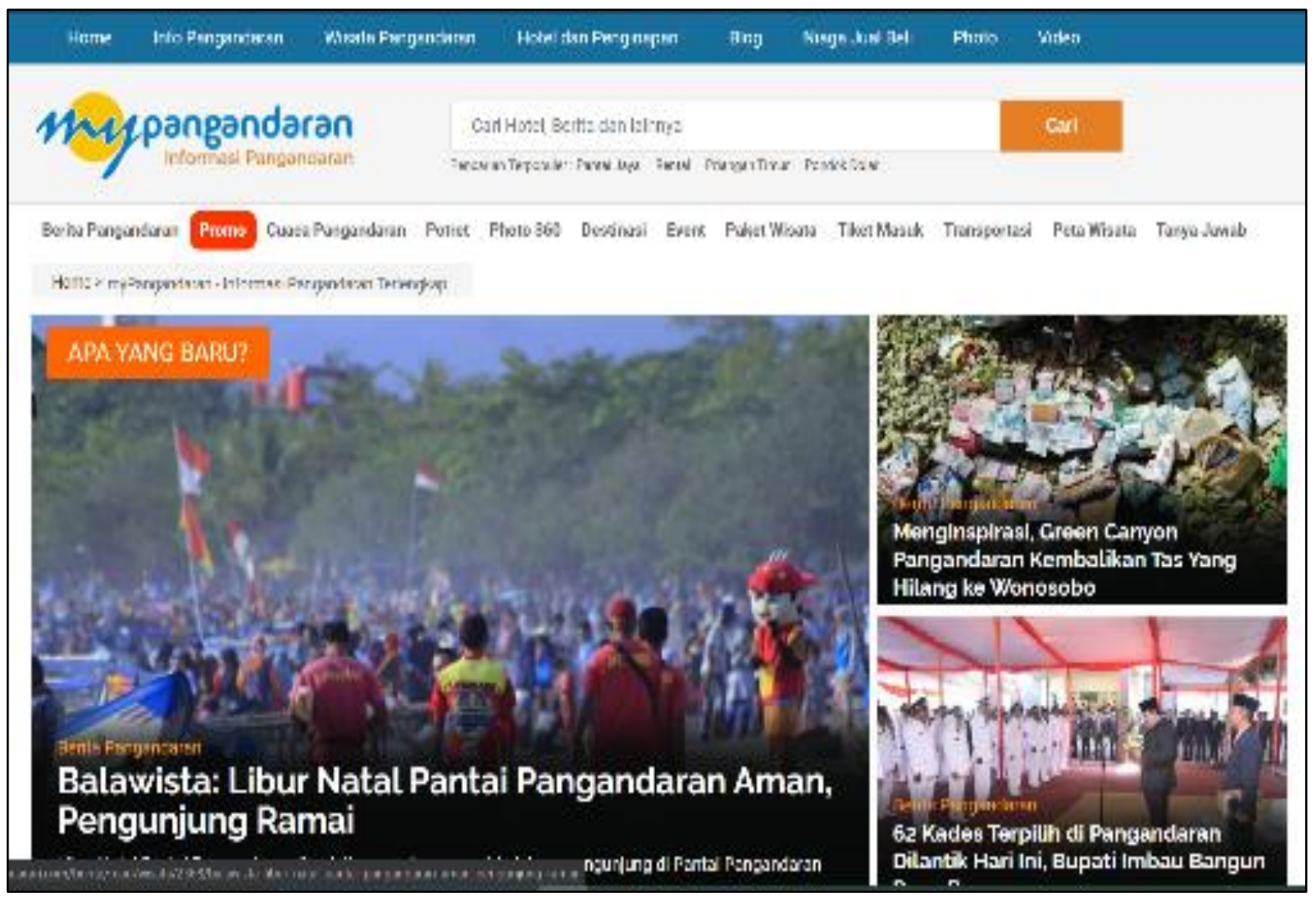

Gambar 2 Website My Pangandaran

Sumber: My Pangandaran (2020)

Kemudian sudah terdapat website dengan nama "My Pangandaran" yang dikelola oleh swasta. Di mana di dalamnya sudah dimuat informasi seputar daya tarik wisata, event, berita terkini terkait Pangandaran, cuaca Pangandaran, penawaran paket wisata beserta trasnportasi, info tiket masuk, pemesanan akomodasi berupa homestay, hingga fitur tanya jawab untuk wisatawan.

Bahkan My Pangandaran sendiri sudah merancang fitur multichannel dengan menautkan website nya kepada akun Instagram. Di mana hal ini dapat memudahkan calon wisatawan milenial yang notabene memang Instagram user. Dalam fitur Instagram yang dimiliki My Pangandaran sendiri juga sudah tersedia kontak person untuk reservasi Tour \& Travel Organizer di @mypangandarantours, reservasi hotel di @mypangandaranhotels, dan reservasi catering di @mypangandarancatering. 
Hal tersebut akan menjadi bekal potensi dari penerapan smart tourism Pangandaran. Karena hakikatnya dapat mempermudah wisatawan yang merupakan technology user.

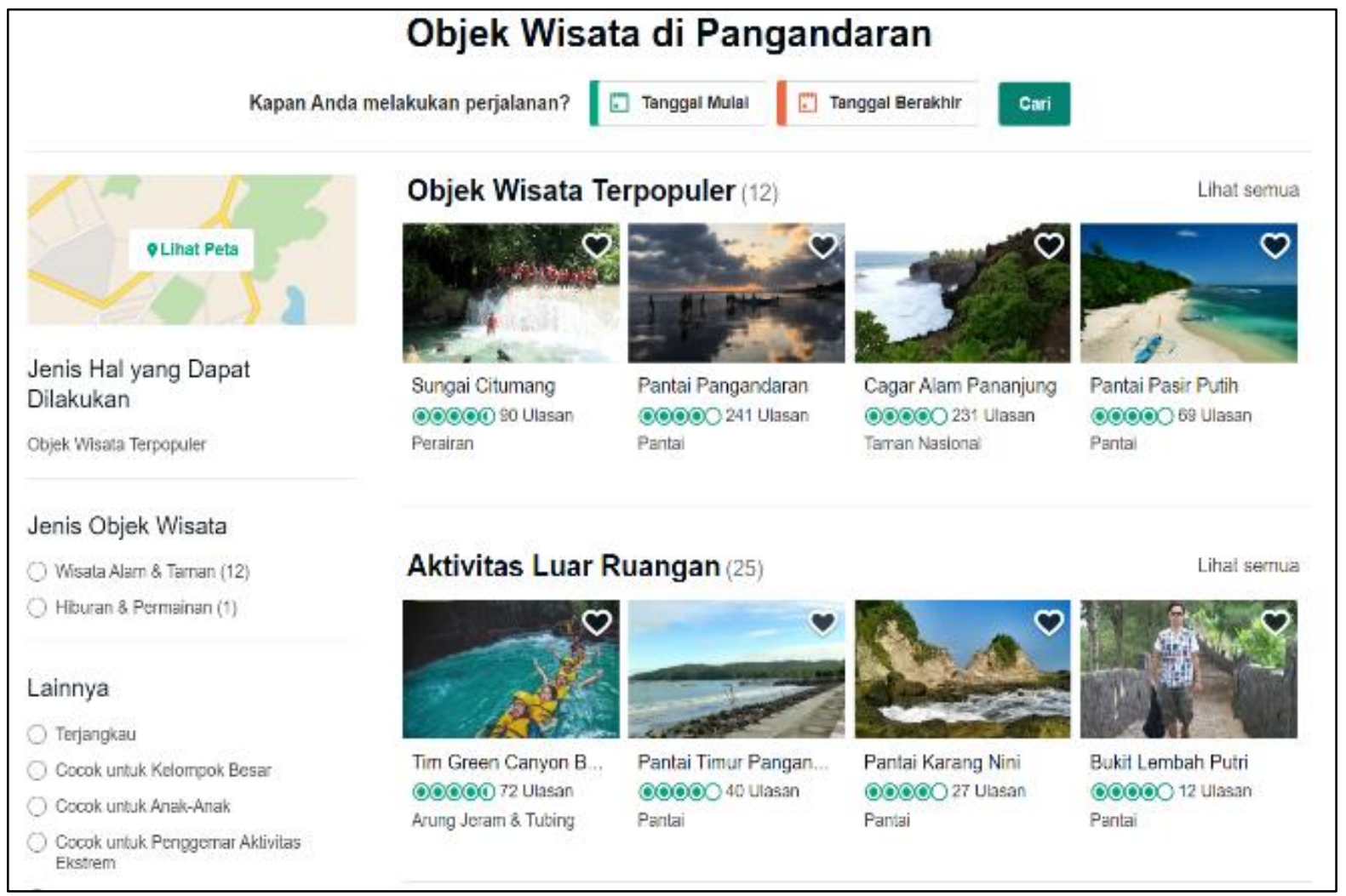

Gambar 3 TripAdvisor Pangandaran

Sumber: Tripadvisor (2020)

Selanjutnya terdapat recommendation systems seperti TripAdvisor. Di mana situs ini merupakan situs wisata terbesar di dunia di bawah naungan Kementerian Pariwisata RI yang membantu wisatawan dalam merencanakan dan memesan perjalanan wisata dengan ulasan-ulasan terkini secara realtime dan berbaiskan penilaian wisatawan yang pernah berkunjung sebelumnya. Namun demikian sangat disayangkan, terkait ticketing untuk memasuki kawasan utama Pantai Indah Pangandaran sendiri, ticketing masih menggunakan sistem manual (kertas) dan tanpa pengamanan portal pengunjung. Sehingga retribusi pun sudah dapat dipastikan tidak akan mendapatkan hasil yang maksimal, berhubung banyak kebocoran dari proses pengamanan ticketing yang tidak optimal. 
Di Kabupaten Pangandaran sendiri, untuk infrastruktur mendasar lainnya seperti ketersediaan jaringan listrik dan sinyal provider antara lain adalah sebagian besar kebutuhan listrik dilayani oleh PT PLN. Pada Tahun 2015 terjual 116.737.897 Kwh dengan jumlah pelanggan sebanyak 94.178 (BPS Kabupaten Ciamis, 2018). Bila dibandingkan dengan tahun 2014 terjadi kenaikan. Hal tersebut disebabkan karena pesatnya pembangunan terutama di sektor perumahan sehingga membutuhkan banyak energi listrik. Pengguna terbanyak listrik masih sama seperti tahun sebelumnya yaitu rumah tangga sebanyak 87.441.088 Kwh (BPS Kabupaten Ciamis, 2018).

Pemerintah melalui PT PLN terus berupaya membangun sarana untuk membangkitkan listrik serta meningkatkan pelayanan kepada pelanggan dengan sebaik-baiknya. Adapun rekapitulasi kondisi kelistrikan dan sinyal provider di tiap kecamatan yang ada di Pangandaran:

Tabel 3. Ketersediaan Listrik dan Kondisi Sinyal Provider di Tiap Kecamatan Kabupaten Pangandaran

\begin{tabular}{lclll}
\hline Kecamatan & Listrik & $\begin{array}{l}\text { Sinyal } \\
\text { Provider }\end{array}$ & Keterangan \\
\hline Cimerak & $\sqrt{ }$ & Baik & $\begin{array}{l}\text { PLN, semua provider baik di Pantai } \\
\text { Keusiklahur, Jojongor, dan Pacuan Kuda } \\
\text { Legok Jawa }\end{array}$ \\
\hline Cijulang & $\sqrt{ }$ & Cukup & $\begin{array}{l}\text { PLN, tidak semua provider baik (DTW Guha } \\
\text { Bau dan Curug Taringgul) }\end{array}$ \\
\hline Cigugur & $\sqrt{ }$ & Kurang & $\begin{array}{l}\text { PLN dan Provider masih harus dikembangkan } \\
\text { di DTW Curug Leuwileutak dan Gn. Haru } \\
\text { Mandala }\end{array}$ \\
\hline Langkaplancar & $\sqrt{ }$ & Kurang & $\begin{array}{l}\text { PLN dan Provider masih harus dikembangkan } \\
\text { di DTW Sinjang Lawang }\end{array}$ \\
\hline Parigi & $\sqrt{ }$ & Kurang & $\begin{array}{l}\text { Provider masih kesulitan sinyal di DTW } \\
\text { Citumang }\end{array}$ \\
\hline Sidamulih & $\sqrt{ }$ & Cukup & $\begin{array}{l}\text { Dibeberapa desa sinyal provider dapat diakses } \\
\text { khususnya di DTW Dolina Cijumleng }\end{array}$ \\
\hline Pangandaran & $\sqrt{ }$ & Baik & $\begin{array}{l}\text { PLN dan provider performanya sudah baik di } \\
\text { DTW Pantai Timur dan Barat, bahkan CA \& } \\
\text { TWA Pananjung sekalipun }\end{array}$ \\
\hline
\end{tabular}




\begin{tabular}{llll}
\hline Kalipucing & $\sqrt{ }$ & Cukup & $\begin{array}{l}\text { PLN dan provider performa sinyalnya sudah } \\
\text { baik di DTW Pantai Karapayak dan Karang } \\
\end{array}$ \\
& & $\begin{array}{l}\text { Nini, namun kurang baik di Goa Donan dan } \\
\text { Terowongan Wilhelmina }\end{array}$ \\
\hline Padaherang & $\sqrt{ }$ & Cukup & $\begin{array}{l}\text { Akses PLN dan provider harus diperbaiki di } \\
\text { DTW Curug Buton }\end{array}$ \\
\hline Mangunjaya & $\sqrt{ }$ & Baik & $\begin{array}{l}\text { Akses PLN dan provider sudah merata karena } \\
\text { dekat dengan perbatasan administrasi Ciamis }\end{array}$ \\
\hline
\end{tabular}

Sumber: Hasil Olahan Data Peneliti (2019)

Adapun peluang kedepannya adalah pembangunan infrastruktur telekomunikasi Palapa Ring oleh Kominfo, yaitu pembangunan serat optik di seluruh Indonesia sepanjang 36.000 kilometer. Di mana dengan pembangunan infrastruktur ini akan mengakselerasi pertumbuhan dan pemerataan pembangunan sosial ekonomi melalui ketersediaan infrastruktur jaringan telekomunikasi berkapasitas besar yang terpadu bisa memberikan jaminan kualitas internet dan komunikasi yang berkualitas tinggi, aman, dan murah.

\section{Destination Management Organization}

Pemerintah Daerah Kabupaten Pangandaran dalam hal ini Dinas Pariwisata dan Kebudayaan Kabupaten Pangandaran menjadi aktor utama dalam mengelola daya tarik wisata. Sedangkan mayoritas masyarakatnya sudah tergabung dalam Kelompok Masyarakat Penggerak Pariwisata (Kompepar) dengan turut berdagang makanan dengan membuat warung-warung, turut andil dalam mempromosikan daerahnya, dan memanfaatkan peluang ekonomi melalui pariwisata mulai menjadi operator aktifitas wisata, ticketing, pemandu wisata, hingga travel agent.

Hasil laut dari nelayan pun tidak kalah hebatnya, karena untuk memenuhi kebutuhan restoran seafood yang ada di kawasan Pantai Pangandaran, berikut juga dengan aneka olahan oleh-oleh nya. Sedangkan kelembagaan lain selain dari pihak pemerintah dari Dinas Pariwisata dan Kebudayaan Pangandaran dan masyarakat dari Kompepar, ada pula kelompok bisnis seperti ASITA dan HPI. 
Kemudian untuk pihak yang langsung bersentuhan dengan teknologi untuk promosi pariwisata sendiri, belum ada kolaborasi langsung dengan perusahaan di bidang teknologi, melainkan media promosi masih dikelola oleh Dinas Pariwisata dan Kebudayaan Kabupaten Pangandaran langsung, karena belum adanya badan promosi pariwisata daerah. Kemudian dari pihak swasta sendiri, baru ada satu badan yang mengelola lansung My Pangandaran.

\section{Wisatawan Potensial}

Berdasarkan laporan laboratorium pariwisata, Magister Pariwisata Berkelanjutan, Universitas Padjadjaran (2019), dari 150 sampel wisatawan Pangandaran yang dilakukan survey, karakteristik mereka mereka berdasarkan rentan usia sebanyak 74\% berumur 21-40 tahun. Di mana menurut Kupperschmidt (2000) generasi milenial atau generasi Y sebagai kelompok orang-orang yang lahir di awal tahun 1980an sampai 2000an. Dalam Undang-Undang No. 40 Tahun 2009 tentang Kepemudaan juga termaktub bahwa generasi muda adalah yang berusia antara 16 tahun sampai 30 tahun.

Sedangkan menurut Chowindra (2015) dan Noviyanti (2014), generasi tersebut memiliki kesukaan terhadap kegiatan wisata dengan perilaku yang unik seperti spontan, memiliki pengetahuan destinasi wisata yang lebih banyak, lebih aktif mencari informasi terkait dengan destinasi wisata terbaru, tidak butuh waktu terlalu banyak untuk mengatur perjalanannya, dan mudah terpengaruh pada ulasan-ulasan destinasi wisata di internet terutama pada media sosial. Hal tersebut karena generasi tersebut merupakan generasi pertama yang tumbuh dengan teknologi di ujung jari mereka (Yoeman, 2012 dalam Honeybell, 2017).

Maka dapat dikatakan mayoritas wisatawan yang datang ke Pangandaran adalah wisatawan milenial. Di mana hal ini dapat menjadi potensi permintaan untuk destinasi dengan konsep smart tourism yang mengedepankan kemudahan akses teknologi di dalamnya. 


\section{Konsep Pengembangan Smart Tourism di Kabupaten Pangandaran}

Smart tourism di Kabupaten Pangandaran, maka konsep pengembangan smart tourism di Kabupaten Pangandaran terbagi ke dalam faktor penawaran dan faktor permintaan (lihat gambar 4). Faktor permintaan didasarkan kepada potensi kunjungan wisatawan milenial ke Pangandaran. Di mana karakteristik mereka dalam mencari informasi terkait destinasi wisata lebih aktif dan mudah mengambil keputusan berkunjung pada ulasan rekan atau wisatawan lainnya baik melalui WOM (Word of Mouth) atau E-WOM (Electronic Word of Mouth).

Kemudian, faktor penawaran terbagi ke dalam organisasi pengelola destinasi (di mana SKPD Kepariwisataan Pangandaran harus segera dibentuk juga Badan Promosi Pariwisata Daerah Kabupaten Pangandaran dan kolaborasi bersama Dinas Komunikasi Informatika Statistik dan Persandian Kabupaten Pangandaran, kemudian dari pihak BUMN dapat berkolaborasi dengan Telkom Indonesia), kemudian pengembangan smart technology and solution (Smart Card untuk akses DTW, Sosial Media berupa Instagram, Twitter, dan Facebook untuk Pangandaran.Tourism, Website My Pangandaran, aktifitas interpretasi melalui VR dan AR, aplikasi reservasi wisata Pangandaran, Wi-fi untuk fasilitas publik, sistem rekomendasi baik itu melalui ulasan TripAdvisor atau pemanfaatan GPS untuk informasi sebaran kepadatan wisatawan dan QR Codes untuk Ticketing atau jenis pembayaran lainnya selama wisata di Pangandaran).

Kemudian faktor penawaran diperkuat dengan pengambilan keputusan berbasiskan Big Data (misalnya, Google Review) untuk meningkatkan pengalaman berwisata dari wisatawan milenial. Lalu untuk mengemas konten promosi digital atau Go Digital, pihak DMO (Destination Management Organization) harus memperhatikan Data Driven (untuk membagikan segala bentuk informasi mengenai pariwisata Pangandaran), Real Time (memberikan informasi terkini dan tanggap respon dengan cepat ke pada wisatawan), Context Aware (memperhatikan dan fokus 
kepada konteks promosi pariwisata), Co-created atau Engage (menjalin interaksi dengan wisatawan untuk menciptakan nilai), Educate (bermanfaat), Entertaint (interaktif dan menghibur), Multichannel (tidak bergantung pada 1 media sosial), Go Visual (menampilkan short tourism video yang menarik dari daya tarik wisata Pangandaran baik budaya ataupun alam), Think like publisher (membuat website yang menarik), Target Your Niche (kolaborasi untuk endorsement kepada travel influencer) dan Listen (mendengarkan feedback wisatawan untuk dimanfaatkan sebagai pengambilan keputusan oleh $\mathrm{DMO})$.

Namun demikian, menurut Putra, R. R (2019), dalam mengoptimalisasi suatu pengembangan destinasi, DMO harus terlebih dahulu dibina dan dilibatkan pelatihan untuk meningkatkan kapasitas dan kapabilitas antar lembaga dan juga sosialisasi dengan masyarakat luas untuk kemudian melibatkannya dalam rencana pengembangan mulai dari tahap perencanaan hingga pengelolaan. Sehingga masyarakat dapat merasakan manfaat langsung dari dampak promosi pariwisata secara Go Digital.

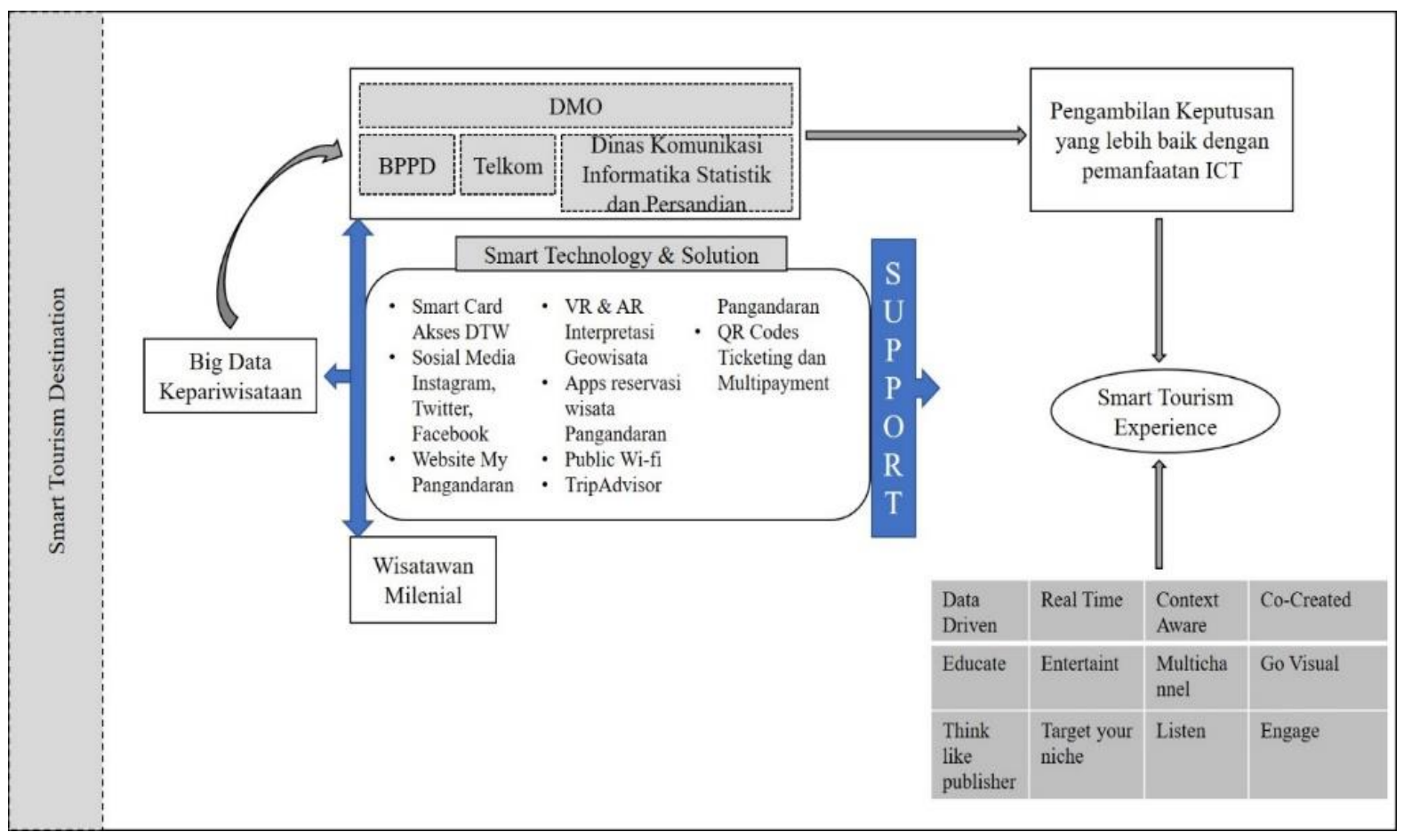

Gambar 4 Konsep Smart Tourism Destination Pangandaran Sumber: Peneliti (2020) 
Kemudian, dalam konteks smart tourism, penataan destinasi yang sedang dikembangkan oleh Dinas Pariwisata dan Kebudayaan Kabupaten Pangandaran juga dapat diinisiasati dengan perencanaan pola spasial daya saing destinasi Pangandaran itu sendiri. Karena suatu destinasi merupakan sebuah wilayah dengan kombinasi dari berbagai daya tarik wisata dan sumber daya lokal. Maka dari itu pola spasial yang dimanage dengan baik, akan memberikan pola perjalanan wisatawan yang tidak menjenuhkan, meningkatkan lama tinggal hingga menciptakan repeat tourist, menjadi rekayasa penyebaran wisatawan untuk menghindari daya dukung dan daya tampung kawasan yang berlebih, dan menjadi suksesi dari destinasi wisata yang cerdas (smart) dan berdaya saing.

Secara eksisting, pola spasial destinasi yang berpotensi diterapkan di Pangandaran sendiri yaitu adalah pola base camp. Di mana pola tersebut merupakan pola perjalanan langsung dari daerah asal wisatawan menuju destinasi utama yang kemudian dijadikan sebagai atau tempat tinggal sementara untuk mengunjugi berbagai daya tarik wisata sekitanya di dalam destinasi utama.

Pola ini bertipikal diversifikasi daya tarik wisata (Lue et al., 1993 dalam Koo et al., 2016), di mana destinasi ini menjual pola perjalanan dengan menampung wisatawan di kawasan atau resort utama terlebih dahulu dengan akses yang mudah dan fasilitas yang one stop service sebelum menyebar ke daya tarik wisata dengan cluster tematik yang berbeda-beda. Konsep ini sejalan dengan apa yang diutarakan oleh Kepala Dinas Pariwisata dan Kebudayaan Kabupaten Pangandaran yang mengatakan bahwa:

“...Untuk membuat wisata yang berkelanjutan itu wisatawan harus diurus. Dimanjakan makannya, dimanjakan penginapannya, supaya betah... Daya tarik wisata harus bersaing... Ga cuma alam aja, aktivitas juga harus ada baik dari budayanya. Ga Cuma atraksinya aja, tapi juga harus ada amenitasnya. Baik hotel, restoran, travel agent, jasa kepemanduan. Segala macam pokonya, mulai dari tempat penukaran uang, harus ada 
Pemanfaatan Teknologi Informasi dan Komunikasi dalam Penerapan Konsep Smart Tourism...

semuanya. Pangandaran udah punya itu, jadi berkelanjutan gitu. Wisatawan pasti betah balik lagi. Jadi nginep satu hari di Pangandarannya, besoknya ke Citumang, Pepedan, dan lain-lain seterusnya...Pangandaran disini menjadi core nya..." (Sohbarudin, Undang., 17/10/2019)

Berdasarkan kutipan wawancara tersebut, yang dimaksudkan dengan Pangandaran dengan fasilitas yang lengkap itu sendiri adalah Kecamatan Pangandaran, di mana Pantai Indah Pangandaran berada dan menjadi pusat kegiatan pariwisata dan daya tarik wisata primer dengan amenitas yang sudah lengkap. Sehingga apabila Kabupaten Pangandaran menerapkan pola spasial base camp, wisatawan akan dapat dengan mudah memilih berbagai macam pilihan akomodasi beserta fasilitas penunjang lainnya melalui bantuan pelayanan digital smart tourism.

Kemudian, wisatawan dapat dibantu dengan media digital tersebut mencari informasi terkait cluster daya tarik wisata tematik yang tersebar di Kabupaten Pangandaran, mulai dari spesifikasinya berdasarkan 3A (atraksi, amenitas, aksesibilitas), sistem informasi geografis (untuk memandu ke kawasan wisata), kemudian VR dan AR untuk media interpretasi pada daya tarik wisata, dan lain hal sebagainya tentunya dapat dipermudah penyebaran wisatawannya melalui media teknologi terbaru. Apabila dipetakan, mulai dari pola di mana wisatawan asal datang, titik area penampung atau pengumpul (gateway complex), hinga sebaran daya tarik wisata yang akan dikunjungi wisatawan, setelah mereka tiba di zona pintu masuk kawasan Pantai Indah Pangandaran, maka peta pola spasial destinasi pariwisata Kabupaten Pangandaran adalah sebagai berikut pada Gambar 5 di bawah ini. 

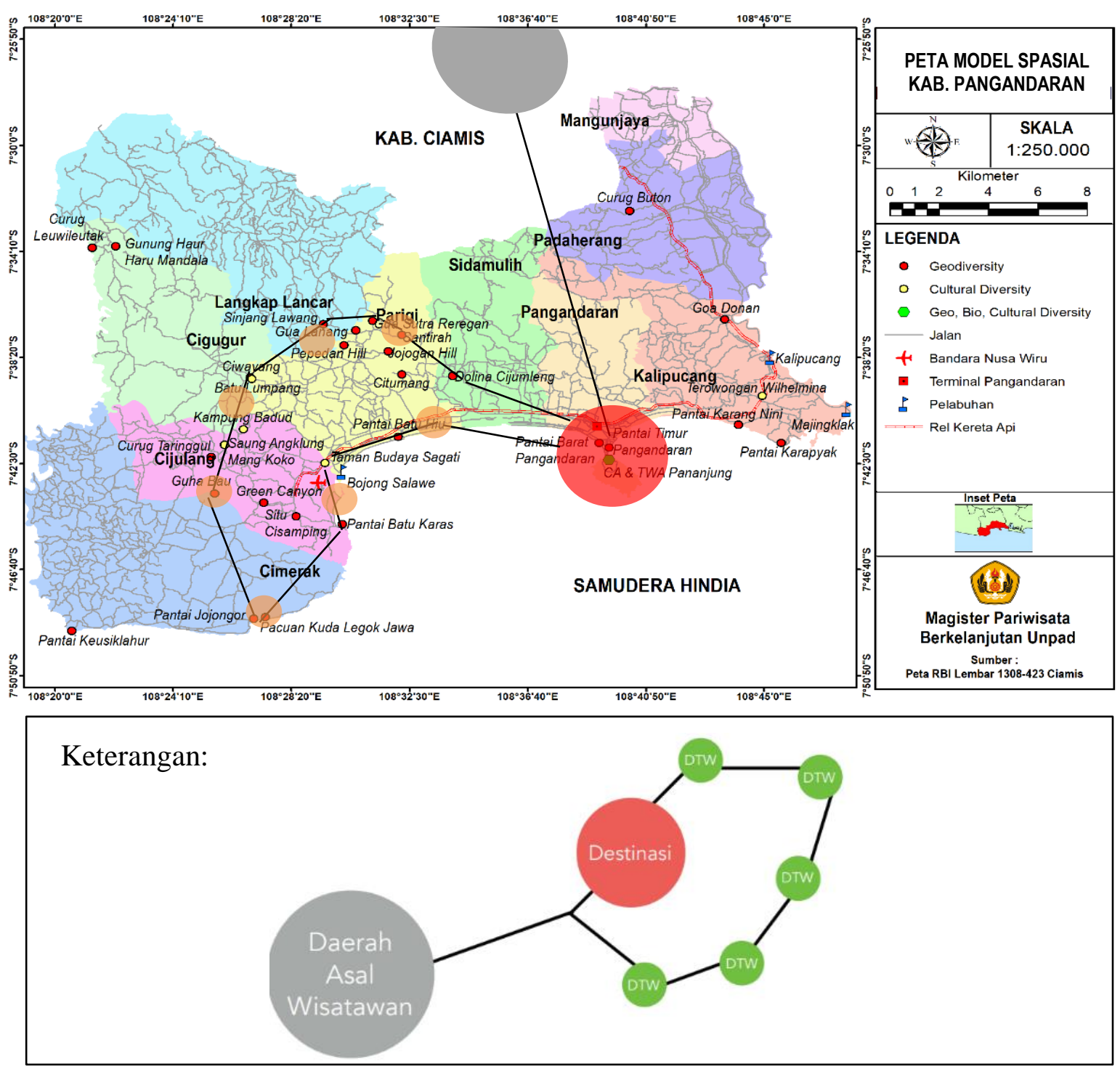

Gambar 5 Peta Pola Spasial untuk Smart Tourism Pangandaran Sumber: Olahan Peneliti (2020)

\section{Simpulan}

Potensi eksisting Kabupaten Pangandaran sebagai Smart Tourism Destination antara lain adalah infrastruktur berbasis teknologi seperti sudah terdapatnya sosial media Instagram Pangandaran.tourism, website My Pangandaran dan juga recommendation systems TripAdvisor Pangandaran. Begitupun ketersediaan listrik dan sinyal provider di tiap kecamatan sudah nyaris merata. DMO Pangandaran yang terlbiat saat ini belum ada BPPD dan juga kolaborasi dengan perusahaan teknologi, 
Pemanfaatan Teknologi Informasi dan Komunikasi dalam Penerapan Konsep Smart Tourism...

melainkan baru sebatas oleh SKPD Kepariwisataan Kabupaten Pangandaran, pihak swasta dari My Pangandaran, ASITA, HPI dan pihak masyarakat dari Kompepar. Wisatawan potensial atau calon pasar dari smart tourism destination Pangandaran berdasarkan hasil survey ada 74\% dari 150 wisatawan yang tergolong ke dalam wisatawan milenial. Adapun konsep pengembangan smart tourism destination Pangandaran terbagi ke dalam faktor permintaan (wisatawan milenial) dan faktor penawaran seperti DMO dengan pembentukan BPPD dan kolaborasi dengan Telkom, juga Diskominfo Statistik dan Persandian Kabupaten Pangandaran, juga pengembangan smart technology beserta faktor pendukung lainnya demi terciptanya pengalaman yang berkesan bagi smart tourists.

\section{Ucapan Terima Kasih}

Dalam proses pembuatan penelitian ini, penulis ingin mengucapkan terima kasih kepada pihak Dinas Pariwisata dan Kebudayaan Kabupaten Pangandaran, khususnya jajaran staf yang telah membantu penulis baik sebagai informan sekaligus atas masukan yang diberikan. Penulis juga ingin mengucapkan terima kasih kepada seluruh responden dan informan lainnya yang berperan dalam penyelesaian penelitian ini. Lebih lanjut lagi, ucapan terima kasih juga penulis dedikasikan kepada kedua orang tua dan keluarga besar. Terakhir, tidak lupa penulis juga ingin mengucapkan terima kasih kepada para dosen dan pegawai di lingkungan Program Magister Pariwisata Berkelanjuran, Sekolah Pascasarjana, Universitas Padjadjaran.

\section{Daftar Pustaka}

Benckendorff, P., Fesenmaier, D. F., \& Sheldon, J. P. 2014. Tourism Information Technology (Second Edition). CAB International.

BPS Kab. Ciamis. 2018. Kabupaten Pangandaran dalam Angka 2018. Ciamis: Badan Pusat Statistik.

Buhalis, D \& O'Connor, P. 2005. Information Communication Technology Revolutionizing Tourism. Tourism Recreation Research, 30 (3), 7-16. 
Buhalis, D. 1998. Strategic Use of Information Technologies in the Tourism Industry. Tourism Management 19(3): 409-423.

Buhalis, D. 2003. E-Tourism: Information Technology for Strategic Tourism Management. Cambridge. Pearson.

Chowindra, C. 2015. Studi Deskriptif Perilaku Generasi Muda Surabaya dalam Melakukan Aktivitas Berwisata. Calyptra: Jurnal Ilmiah Mahasiswa Universitas Surabaya, 4(1).

Data Sekretariat Dinas Pariwisata dan Kebudayaan Kabupaten Pangandaran dan Perum Perhutani Ciamis Tahun 2019.

Dewantara, M. H. 2015. Analisis dan Pengembangan Situs Resmi Pariwisata Indonesia dan Sistem Informasi Pendukungnya. JUMPA, 1(2), 9-24.

Femenia-Serra, Fransisco \& Neuhofer, Barbara. 2019. Smart Tourism Experiences: Conceptualisation, Key Dimension adn Research Agenda. Investigaciones Regionales - Journal of Regional Research, 42, 129 - 150.

Gajdosik, Tomas. 2018. Smart Tourism: Concepts and Insights from Central Europe. Czech Journal of Tourism. Vol 1.

Heliany, I. 2019. Wonderful Digital Tourism Indonesia dan Peran Revolusi Industri dalam Menghadapi Era Ekonomi Digital 5.0. Destinesia Jurnal Hospitaliti dan Pariwisata, 1 (1), 21-35.

Honeybell, E. 2017. Determining The Motivations of Millenial Travellers in The Context of Cultural Experiences in Southeast Asia. Cardiff Metropolitan University: Master Desertation, International Tourism Management (Retreived from:

https://repository.cardiffmet.ac.uk/bitsream/handle/10369/8728/Eleanor\%20H oneyball\%20Disertation.pdf?sequence $=1$ ).

Kementrian Kominikasi dan Informatika RI. 2018. Pengguna Internet No 6 Di Dunia. (Retreived from: https://kominfo.go.id/content/detail/4286/pengguna-internetindonesia-nomor-enamdunia/0/sorotan_media 25/12/2019).

Koo, C., Gretzel, U., Hunter, W. C., \& Chung, N. 2016. Conceptualization of Smart Tourism Destination Competitiveness. Asia Pacific Journal of Information Systems, 26(4), 367-384.

Kupperschmidt, B. R. 2000. Multigenerational employees: Strategies for effective management. The Health Care Manager, 19, 65-7. 
Lamsfus, C., Martín, D., Alzua-Sorzabal, A. and Torres-Manzanera, E. 2015. Smart Tourism Destinations: An Extended Conception of Smart Cities Focusing on Human Mobility. in Information and Communication TechNologies in Tourism 2015 Springer, 363-375.

Lopez de Avila, A. 2015. Smart destinations: XXI century tourism. ENTER 2015 Conference on Information and Communication TechNologies in Tourism, LugaNo, Switzerland.

Miles, M. B., Huberman, A. M., \& Saldana, J. 2014. Qualitative Data Analysis (Third Edition). SAGE Publications, Inc.

Noviyanti, S. 2014. WIsatawan Muda Meningkat di Asia. Kompas.com. (Retrieved from: https://ravel.kompas.com/read/2014/08/27/15110927/Wisatawan.muda .meningkat.di.Asia).

O'connor, P. 1999. Electronic Information Distribution in Tourism Hospitality. Oxford. CABI.

Peraturan Pemerintah Republik Indonesia Nomor 50 Tahun 2011 Tentang Rencana Induk Pembangunan Kepariwisataan Nasional Tahun 2010-2025.

Poon, A. 1993. Tourism, Technology and Competitive Strategies. Oxford. CAB International.

Puspawigati, A. 2014. Pemasaran Pariwisata Pulau Pramuka Oleh Suku Dinas Pariwisata dan Kebudayaan Kepulauan Seribu dalam Meningkatkan Jumlah Kunjungan Wisatawan. Skripsi: Universitas Gadjah Mada. (Retreived from: http://etd.repository.ugm.ac.id/.

Putra, R. R., Dienaputra, R. D., Nugraha, A., Khadijah, U. L. S., \& Rakhman, C. U. 2019. Optimalisasi Rencana Pengembangan Daya Tarik Wisata Berkelanjutan: Studi Kasus di Situ Cigayonggong. Media Bina Ilmiah, 14(3), 2317-2330.

Sheldon, P. 1997. Information Technologies for Tourism. Oxford. CAB International.

Undang-Undang RI No. 40 Tahun 2009 tentang Kepemudaan.

Universitas Padjadjaran. 2019. Pengembangan Pariwisata untuk Aspiring Geopark Pangandaran. Laporan Laboratorium Pariwisata, Magister Pariwisata Berkelanjutan, Sekolah Pascasarjana, Universitas Padjadjaran. [tidak diterbitkan].

Werthner, H \& Ricci, Franceso. 2004. E-commerce and tourism. Journal Communication of The ACM. 


\section{Profil Penulis}

Rifki Rahmanda Putra, S.Par adalah mahasiswa Magister Pariwisata Berkelanjutan, Sekolah Pascasarjana, Universitas Padjadjaran. Sebelumnya, beliau menyelesaikan program studi Strata I, Manajemen Resort \& Leisure di Universitas Pendidikan Indonesia. Beliau pernah melakukan program on Job Training di bidang Ekosistem Pariwisata, Asisten Deputi Pengembangan Infrastruktur dan Ekosistem Pariwisata, Deputi Pengembangan Destinasi dan Industri Pariwisata, Kementerian Pariwisata Republik Indonesia. Dalam program studinya di Universitas Pendidikan Indonesia, beliau melakukan riset skripsi dengan judul Perencanaan Atraksi Wisata di Situ Cigayonggong Desa Kasomalang Wetan Kecamatan Kasomalang Kabupaten Subang, yang sekaligus menjadi bidang yang diminatinya. Sedangkan selama di Universitas Padjadjaran, beliau pernah membuat beberapa karya tulis ilmiah diantar anya: 1) Book Chapter “Menemukenali Tipologi Wisatawan Guna Mendukung Keberlanjutan Destinasi Pariwisata Jawa Barat" pada Buku Potensi Pariwisata Jawa Barat yang dirilis oleh UNPAD PRESS; 2) "Educational Tourism and Its Development Program in Supporting Sustainable Regional Development at Padjadjaran University" yang diseminarkan pada The 1st ICTE Belitung; 3) “Development of Educational Tourism Program: Case Study ini Universitas Padjadjaran Jatinangor" yang dikompetisikan pada 8th UIYEA International Paper Competition Universitas Indonesia; 4) “Optimalisasi Rencana Pengembangan Daya Tarik Wisata Berkelanjutan: Studi Kasus di Situ Cigayonggong" yang dipublikasikan pada MEDIA BINA ILMIAH; dan 5) “Tipologi, Motivasi dan Karakteristik Perilaku Komunitas Pecinta Alam Wanadri dalam Melakukan Aktivitas Wisata Alam" yang akan dipublikasikan oleh Jurnal Pesona Pariwisata. 
Dr. Ute Lies Siti Khadijah, M.Si adalah dosen pengajar di Magister Pariwisata Berkelanjutan, Sekolah Pascasarjana, Universitas Padjadjaran. Beliau mengampu Mata Kuliah Metodologi Penelitian Pariwisata dan Mata Kuliah Pariwisata Budaya dan Heritage. Kepakaran beliau adalah pariwisata berbasis masyarakat, pariwisata budaya dan heritage, juga terkait metodologi penelitian sosial. Beliau banyak melakukan riset mengenai partisipasi dan pemberdayaan masyarakat dalam kegiatan mitigasi bencana di kawasan wisata, juga penelitian terkait preservasi warisan budaya

Dr. Cecep Ucu Rakhman, M.Hum adalah dosen tetap di Sekolah Tinggi Pariwisata Bandung dan juga sebagai dosen pengajar di Magister Pariwisata Berkelanjutan, Sekolah Pascasarjana, Universitas Padjadjaran. Beliau menjadi tenaga pengajar pada Mata Kuliah Manajemen Krisis Kepariwisataan. Kepakaran beliau adalah pariwisata berbasis masyarakat, pariwisata budaya, juga terkait manajemen krisis kepariwisataan. Beliau banyak melakukan riset mengenai pemberdayaan masyarakat dan pariwisata budaya. 